\title{
Pollution Status of Metals in Sediments from Ikere, Iseyin, Opeki, Ofiki and Igangan Sections of the Ogun River Basin
}

\author{
Anslem Diayi $^{1^{*}}$ and A.M. Gbadebo ${ }^{1}$ \\ Department of Environmental Management \& Toxicology University of Agriculture, P.M.B. 2240, Abeokuta, \\ Ogun-State, Nigeria
}

\begin{abstract}
Sediments were obtained from sections of the Ogun River namely Ikere, Iseyin, Opeki, Ofiki and Igangan. Layers of sediment ranging from $0-5 \mathrm{~cm}, 5-10 \mathrm{~cm}$ and $10-15 \mathrm{~cm}$ were obtained after which they were air dried, pulverized and sieved using a $2 \mathrm{~mm}$ sieve to obtain very fine grain particles for analysis. The sediments were then subjected to physicochemical analysis in which $\mathrm{pH}$ and conductivity were determined using standard methods by the American Public Health Association of 1992 while Organic Carbon was determined by Wakley Method. For the sediment metal analysis, sediments were subjected to the Induced Couple Plasma/Mass Spectrometer (ICP/MS) analysis. Results obtained were then used for the calculation of the Geochemical Pollution Intensity (Igeo). Metal results obtained showed that all metals had concentrations lower than Environment Canada Sediment Quality Guideline standards of 35.70ppm, 35.00ppm, 0.60ppm, 123.00ppm, 5.90 ppm, 0.17ppm and 37.50ppm for $\mathrm{Cu}, \mathrm{Pb}, \mathrm{As}, \mathrm{Zn}, \mathrm{Hg}, \mathrm{Cd}$, and $\mathrm{Cr}$ respectively except that of $\mathrm{Pb}$ obtained from Opeki $0-5 \mathrm{~cm}$ with value of $80.80 \mathrm{ppm}$ which was higher than the $35.00 \mathrm{ppm}$ standard limit. Thus, this sediment layer requires frequent monitoring as toxic levels of Pb can be harmful to sediment/aquatic species. All Igeo values showed unpolluted status for the metals analyzed.

Key words: Metals, sediment, Limits, Concentration and Value
\end{abstract}

\section{Introduction}

Sediments are an essential component of fresh water system because they serve as a sink for heavy metals while providing habitat for organisms. Mgbemena et. al., (2011) stated that sediments are substrates for organisms and they play major role in aquatic ecosystem by reason of their interaction with water.

As a known sink for the accumulation of heavy metals, sediments can make accumulated metals available to fresh water ecosystem. According to Elijah et. al., (2008), dredging has been reported to cause the re-mobilization of contaminants particularly heavy metals on aquatic animals and plants. Heavy metals are a threat to aquatic species. The impact posed on these species arise from their toxicity, biological processes as well as bio-accumulative characteristics (Mgbemena et. al., (2011)). Toxic metals produce deleterious effects on aquatic species when present in the species at high concentrations.

This study is aimed at determining the concentrations of metals in sediments as well as the physicochemical parameters which will aid in the monitoring of sediment quality in relation to the aquatic environment since the Ogun River serves as a source of water supply to the people of Ogun and Lagos states respectively.

\section{Experimental methods}

\section{Materials And Methods}

Collection of sediments from of depths $0-5 \mathrm{~cm}, 5-10 \mathrm{~cm}, 10-15 \mathrm{~cm}$ were done from Ikere, Iseyin, Opeki, Ofiki and Igangan areas of the upper region of the Ogun River course between January to March, 2012. Using a graduated sediment grab, five samples were collected per location/layer after which they were composited (for each layer in a location). Sediments collected were then transferred into polythene bags and placed in an ice chest cooler for onward transportation to the laboratory. The $\mathrm{pH}$ and conductivity values were determined using standard methods by APHA (1992) while value for organic carbon was determined by Black and Wakley's Method. At the laboratory, sediment samples were air-dried, pulverized and sieved using a $2 \mathrm{~mm}$ sieve to remove coarse particles. The finer sediments $(<2 \mathrm{~mm})$ were then subjected to the Induced Couple Plasma Mass Spectrometry (ICP/MS) for determination of concentrations of Copper (Cu), Cadmium (Cd), Zinc $(\mathrm{Zn})$, Mercury (Hg), Nickel (Ni), Lead ( $\mathrm{Pb})$, Arsenic (As), Chromium (Cr), and Manganese (Mn) while the geochemical pollution indices were determined using the mathematical equation "Igeo $=\log 2(\mathrm{Cn} / 1.5 \mathrm{Bn})$ " introduced by Muller (1979) (where Cn refers to heavy metal concentration in sediment of study area, $\mathrm{Bn}$ is the geochemical background value in average shale of element and 1.5 is the background matrix correction factor due to lithogenic effects while Igeo is the Geochemical Accumulation Index). 


\section{Sampling areas}

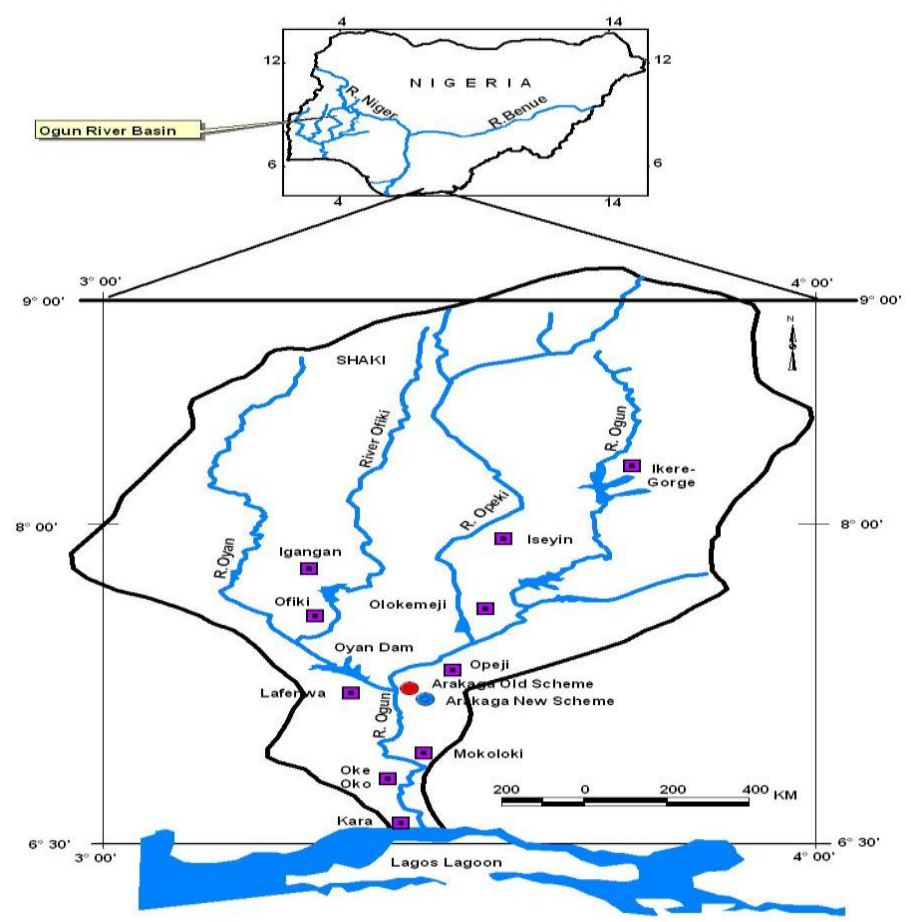

Fig 1: The Ogun River Basin

Areas sampled include; Ikere, Iseyin, Opeki, Ofiki and Igangan. These areas are generally characterized by low population densities with fishing, wood collection and sand dredging as predominant activities. The presence of a dam was observed at Ikere Gorge. The Ogun-River, located in Ogun-State, South West of Nigeria lies between latitude $6^{\circ} 35^{\prime}$ and $8^{\circ} 58^{\prime}$ North with Longitude $2^{\circ} 40^{\prime}$ and $4^{\circ} 10^{\prime}$ East. It rises from Iganran Hills, east of Shaki, Oyo state, South West, Nigeria (latitude $07^{\circ} 40^{\prime} \mathrm{N}$ and Longitude $03^{\circ} 20^{\prime} \mathrm{E}$ ). The entire river basin (Ogun River) occupies an area of approximately $23,700 \mathrm{~km}^{2}$ (OORBDA, 1982).

\section{Quality assurance}

Three replicates were taken per sample analyzed. A series of standard reference materials were used for sediment samples. These included STD OREAS45CA, STD DS9 and BLK.

III. Results And Discussion

Table 1: Physicochemical Analysis

\begin{tabular}{lcccccc}
\hline Location & pH & EC & Organic Carbon & Sand & Clay & Silt \\
& $(\mu \mathrm{S} / \mathrm{cm})$ & $(\%)$ & $(\%)$ & $(\%)$ & $(\%)$ & \\
\hline Ikere $(0-5 \mathrm{~cm})$ & 8.05 & 76.00 & 1.80 & 96.00 & 0.00 & 3.60 \\
Ikere $(5-10 \mathrm{~cm})$ & 7.60 & 52.00 & 1.40 & 92.80 & 1.80 & 5.40 \\
Ikere $(10-15 \mathrm{~cm})$ & 8.40 & 36.00 & 1.40 & 91.00 & 1.80 & 7.20 \\
Iseyin $(0-5 \mathrm{~cm})$ & 8.47 & 135.00 & 0.60 & 100.000 .00 & 0.00 \\
Iseyin $(5-10 \mathrm{~cm})$ & 10.40 & 78.00 & 3.40 & 96.40 & 0.00 & 3.60 \\
Iseyin $(10-15 \mathrm{~cm})$ & 9.10 & 36.00 & 0.00 & 100.000 .00 & 0.00 \\
Ofiki $(0-5 \mathrm{~cm})$ & 8.40 & 34.00 & 2.40 & 96.40 & 0.00 & 3.60 \\
Ofiki $(5-10 \mathrm{~cm})$ & 8.80 & 33.00 & 2.60 & 96.40 & 0.00 & 3.60 \\
Ofiki $(10-15 \mathrm{~cm})$ & 8.30 & 37.00 & 1.80 & 100.000 .00 & 0.00 \\
Opeki $(0-5 \mathrm{~cm})$ & 9.20 & 87.00 & 1.60 & 100.000 .00 & 0.00 \\
Opeki $(5-10 \mathrm{~cm})$ & 10.00 & 71.00 & 1.40 & 100.000 .00 & 0.00 \\
Opeki $(10-15 \mathrm{~cm})$ & 8.80 & 86.00 & 0.60 & 100.000 .00 & 0.00 \\
Igangan $(0-5 \mathrm{~cm})$ & 8.30 & 47.00 & 1.00 & 96.40 & 0.00 & 3.60 \\
Igangan $(5-10 \mathrm{~cm})$ & 8.30 & 37.00 & 3.20 & 96.40 & 0.00 & 3.60 \\
Igangan $(10-15 \mathrm{~cm})$ & 8.10 & 42.00 & 3.40 & 100.000 .00 & 0.00 \\
\hline
\end{tabular}


Pollution Status of Metals in Sediments from Ikere, Iseyin, Opeki, Ofiki and Igangan Sections of the

TABLE 2: TRACE METAL CONCENTRATION (PPM)

\begin{tabular}{|c|c|c|c|c|c|c|c|c|c|}
\hline Location & $\mathrm{Cu}$ & $\mathrm{Pb}$ & $\mathrm{Zn}$ & $\mathrm{Ni}$ & $\mathrm{Mn}$ & As & $\mathrm{Cd}$ & $\mathrm{Cr}$ & $\mathrm{Hg}$ \\
\hline Ikere $(0-5 \mathrm{~cm})$ & $5.20 \pm 0.1$ & $8.80 \pm 0.1$ & $18.00 \pm 0.1$ & $2.40 \pm 0.1$ & $136.00 \pm 0.1$ & $0.80 \pm 0.1$ & $0.00 \pm 0.0$ & $21.00 \pm 0.1$ & $0.00 \pm 0.0$ \\
\hline Ikere $(5-10 \mathrm{~cm})$ & $10.00 \pm 0.1$ & $14.80 \pm 0.1$ & $39.00 \pm 0.1$ & $9.30 \pm 0.1$ & $130.00 \pm 0.1$ & $0.00 \pm 0.0$ & $0.00 \pm 0.0$ & $25.00 \pm 0.2$ & $0.00 \pm 0.0$ \\
\hline Ikere $(10-15 \mathrm{~cm})$ & $9.00 \pm 0.1$ & $8.70 \pm 0.1$ & $33.00 \pm 0.1$ & $8.30 \pm 0.1$ & $124.00 \pm 0.2$ & $0.00 \pm 0.0$ & $0.00 \pm 0.1$ & $25.00 \pm 0.2$ & $0.00 \pm 0.0$ \\
\hline Iseyin $(0-5 \mathrm{~cm})$ & $9.00 \pm 0.2$ & $11.40 \pm 0.1$ & $38.00 \pm 0.1$ & $6.90 \pm 0.1$ & $109.00 \pm 0.1$ & $0.00 \pm 0.0$ & $0.00 \pm 0.0$ & $20.00 \pm 0.1$ & $0.00 \pm 0.1$ \\
\hline Isexin $(5-10 \mathrm{~cm})$ & $3.70 \pm 0.1$ & $4.80 \pm 0.2$ & $10.00 \pm 0.2$ & $1.80 \pm 0.0$ & $84.00 \pm 0.1$ & $0.00 \pm 0.1$ & $0.00 \pm 0.0$ & $18.00 \pm 0.1$ & $0.00 \pm 0.1$ \\
\hline Iseyin $(10-15 \mathrm{~cm})$ & $3.10 \pm 0.1$ & $5.30 \pm 0.1$ & $7.00 \pm 0.1$ & $1.70 \pm 0.2$ & $78.00 \pm 0.1$ & $0.00 \pm 0.1$ & $0.00 \pm 0.0$ & $16.00 \pm 0.1$ & $0.00 \pm 0.1$ \\
\hline Ofiki $(0-5 \mathrm{~cm})$ & $3.60 \pm 0.1$ & $5.30 \pm 0.1$ & $21.00 \pm 0.1$ & $3.00 \pm 0.1$ & $101.00 \pm 0.2$ & $0.00 \pm 0.0$ & $0.00 \pm 0.0$ & $9.00 \pm 0.1$ & $0.00 \pm 0.0$ \\
\hline Ofiki $(5-10 \mathrm{~cm})$ & $6.10 \pm 0.1$ & $5.70 \pm 0.1$ & $17.00 \pm 0.2$ & $5.1 \pm 0.1$ & $89.00 \pm 0.2$ & $0.00 \pm 0.0$ & $0.00 \pm 0.0$ & $13.00 \pm 0.1$ & $0.00 \pm 0.0$ \\
\hline Ofiki $(10-15 \mathrm{~cm})$ & $6.20 \pm 0.1$ & $6.10 \pm 0.1$ & $18.00 \pm 0.1$ & $5.00 \pm 0.1$ & $110.00 \pm 0.2$ & $0.00 \pm 0.0$ & $0.00 \pm 0.0$ & $14.00 \pm 0.1$ & $0.00 \pm 0.0$ \\
\hline Opeki $(0-5 \mathrm{~cm})$ & $11.40 \pm 0.1$ & $80.80 \pm 0.2$ & $15.00 \pm 0.1$ & $2.90 \pm 0.1$ & $165.00 \pm 0.2$ & $0.00 \pm 0.0$ & $0.00 \pm 0.0$ & $16.00 \pm 0.1$ & $0.00 \pm 0.0$ \\
\hline Opeki $(5-10 \mathrm{~cm})$ & $10.30 \pm 0.1$ & $7.30 \pm 0.1$ & $12.00 \pm 0.1$ & $2.90 \pm 0.1$ & $153.00 \pm 0.2$ & $0.00 \pm 0.0$ & $0.00 \pm 0.0$ & $19.00 \pm 0.1$ & $0.00 \pm 0.0$ \\
\hline Opeki $(10-15 \mathrm{~cm}) 2$ & $23.70 \pm 0.11$ & $17.00 \pm 0.1$ & $29.00 \pm 0.1$ & $2.60 \pm 0.1$ & $208.00 \pm 0.2$ & $0.00 \pm 0.0$ & $0.00 \pm 0.0$ & $14.00 \pm 0.2$ & $0.00 \pm 0.0$ \\
\hline Igangan $(0-5 \mathrm{~cm})$ & $3.30 \pm 0.1$ & $2.60 \pm 0.1$ & $6.00 \pm 0.1$ & $2.80 \pm 0.1$ & $96.00 \pm 0.2$ & $0.00 \pm 0.0$ & $0.00 \pm 0.0$ & $19.00 \pm 0.1$ & $0.00 \pm 0.0$ \\
\hline Igangan $(5-10 \mathrm{~cm})$ & $2.00 \pm 0.1$ & $2.30 \pm 0.1$ & $5.00 \pm 0.1$ & $2.00 \pm 0.1$ & $84.00 \pm 0.2$ & $0.00 \pm 0.0$ & $0.00 \pm 0.0$ & $9.00 \pm 0.1$ & $0.00 \pm 0.0$ \\
\hline Igangan $(10-15 \mathrm{~cm})$ & n) $3.60 \pm 0.1$ & $2.20 \pm 0.1$ & $6.00 \pm 0.1$ & $2.20 \pm 0.1$ & $110.00 \pm 0.1$ & $0.00 \pm 0.1$ & $0.00 \pm 0.0$ & $9.00 \pm 0.1$ & $0.00 \pm 0.0$ \\
\hline ECSQG & 35.70 & 35.00 & 123.00 & NS & NS & 5.90 & 0.60 & 37.30 & 0.17 \\
\hline
\end{tabular}

TABLE 3: GEOCHEMICAL POLLUTION INDEX

\begin{tabular}{lccccccccc}
\hline Location & $\mathrm{Cu}$ & $\mathrm{Pb}$ & $\mathrm{Zn}$ & $\mathrm{Ni}$ & $\mathrm{Mn}$ & $\mathrm{As}$ & $\mathrm{Cd}$ & $\mathrm{Cr}$ & $\mathrm{Hg}$ \\
\hline Ikere $(0-5 \mathrm{~cm})$ & 0.00 & 0.10 & 0.00 & 0.00 & 0.00 & 0.00 & 0.00 & 0.00 & 0.00 \\
Ikere $(5-10 \mathrm{~cm})$ & 0.05 & 0.15 & 0.10 & 0.00 & 0.00 & 0.00 & 0.00 & 0.05 & 0.00 \\
Ikere $(10-15 \mathrm{~cm})$ & 0.00 & 0.10 & 0.10 & 0.00 & 0.00 & 0.00 & 0.00 & 0.05 & 0.00 \\
Iseyin $(0-5 \mathrm{~cm})$ & 0.00 & 0.00 & 0.10 & 0.00 & 0.00 & 0.00 & 0.00 & 0.00 & 0.00 \\
Iseyin(5-10cm) & 0.00 & 0.00 & 0.00 & 0.00 & 0.00 & 0.00 & 0.00 & 0.00 & 0.00 \\
Iseyin $(10-15 \mathrm{~cm})$ & 0.00 & 0.00 & 0.00 & 0.00 & 0.00 & 0.00 & 0.00 & 0.00 & 0.00 \\
Ofiki $(0-5 \mathrm{~cm})$ & 0.00 & 0.05 & 0.15 & 0.00 & 0.00 & 0.00 & 0.00 & 0.00 & 0.00 \\
Ofiki (5-10cm) & 0.00 & 0.10 & 0.00 & 0.00 & 0.00 & 0.00 & 0.00 & 0.00 & 0.00 \\
Ofiki (10-15cm) & 0.00 & 0.10 & 0.00 & 0.00 & 0.00 & 0.00 & 0.00 & 0.00 & 0.00 \\
Opeki $(0-5 \mathrm{~cm})$ & 0.05 & 0.50 & 0.00 & 0.00 & 0.00 & 0.00 & 0.00 & 0.00 & 0.00 \\
Opeki (5-10cm) & 0.05 & 0.10 & 0.00 & 0.00 & 0.00 & 0.00 & 0.00 & 0.00 & 0.00 \\
Opeki (10-15cm) & 0.10 & 0.20 & 0.10 & 0.00 & 0.05 & 0.00 & 0.00 & 0.00 & 0.00 \\
Igangan $(0-5 \mathrm{~cm})$ & 0.00 & 0.00 & 0.00 & 0.00 & 0.00 & 0.00 & 0.00 & 0.00 & 0.00 \\
Igangan (5-10cm) & 0.00 & 0.00 & 0.00 & 0.00 & 0.00 & 0.00 & 0.00 & 0.00 & 0.00 \\
Igangan (10-15cm) & 0.00 & 0.00 & 0.00 & 0.00 & 0.00 & 0.00 & 0.00 & 0.00 & 0.00 \\
Average Shale & 45.00 & 20.00 & 95.00 & 50.00 & 850.00 & 13.00 & 0.30 & 95.00 & 0.18 \\
Value & & & & & & & & & \\
\hline
\end{tabular}




\section{Discussion}

From the results obtained, it was observed that a range of 2.00 to $23.70 \mathrm{ppm}$ was obtained for $\mathrm{Cu}$ concentration from all the locations surveyed. When compared to the Environment Canada Sediment Quality Guideline standard of $35.70 \mathrm{ppm}$, it was realized that all metal concentrations observed were lower than the standard. This implies that $\mathrm{Cu}$ is not found at a toxic concentration in the areas surveyed. Similarly, all $\mathrm{Zn}$ concentrations (5.00 - $39.00 \mathrm{ppm})$, As concentrations $(0.00-0.80 \mathrm{ppm})$ and $\mathrm{Cr}(9.00-25.00 \mathrm{ppm})$ were lower than the Environment Canada Sediment Quality Guideline standards of $123.00 \mathrm{ppm}, 5.90 \mathrm{ppm}$ and $37.3 \mathrm{ppm}$ respectively. Thus indicating low toxic levels for metals analyzed. This was also confirmed by the unpolluted status observed from the igeo analysis carried out with all values obtained from the analysis having values between 0-1. Based on the igeo analysis, if the value obtained fell between 0-1, the pollution intensity is termed unpolluted, 1-2 is classified as moderately to unpolluted, 2-3 is moderately polluted, 3-4 is moderately to highly polluted, $4-5$ is highly polluted while 5 and above would be classified as very highly polluted. Lead analysis conducted showed that all values obtained were lower than the Environment Canada Sediment Quality Guideline standard of $35.00 \mathrm{ppm}$ except that obtained from Opeki $0-5 \mathrm{~cm}$ with value of $80.80 \mathrm{ppm}$. This value shows high concentration of the metal in that layer of sediment which can be deleterious to aquatic species and humans on the long run when the species are consumed over a long period of time because $\mathrm{Pb}$ is bioaccumulated by benthic bacteria, freshwater plants, invertebrates and fish (DWAF, 1996). Lead is potentially hazardous to most of life, and is considered toxic to aquatic organisms.

All sediment samples analyzed were sandy when subjected particle size analysis. Alkaline $\mathrm{pH}$ ranging from 8.05 to 10.40 were obtained from all the layers of sediment analyzed. Conductivity values obtained ranged from $83-135 \mu \mathrm{S} / \mathrm{cm}$.

\section{Conclusion}

The sandy sediments, alkaline $\mathrm{pH}$ and low conductivity values obtained from all the sediment layers accounted for the low metal concentrations observed in the areas surveyed. Sediments that are high in clay content or that contain finer particles have the ability to accumulate more metals than loosely bounded sediment particles. This was confirmed by Fan et al. (2002) who stated that fine-grained bottom sediments tend to accumulate contaminants due to their sorptive nature, and thus act as an important reservoir by reducing the toxicity potential to aquatic organisms. With an alkaline $\mathrm{pH}$ observed from all layers, the precipitation of certain metals like $\mathrm{Cd}, \mathrm{Cu}, \mathrm{Mn}$ would not be easily encouraged as they favorably released under acidic conditions. From the metal concentration results obtained in which all metals analyzed had values lower than the Environment Canada Sediment Quality Guideline Standards (except for Opeki $0-5 \mathrm{~cm}$ Pb value of $80.80 \mathrm{ppm}$ ), it can be deduced that the metals have low concentrations which implies low toxicity/threat to sediment dwelling organism. Sediment layer for Opeki $0-5 \mathrm{~cm}$ with value of $80.80 \mathrm{ppm}$ for $\mathrm{Pb}$ should be monitored regularly as it was observed to be higher than the Environment Canada Sediment Quality Guideline Standard of 35.00ppm. Since most of the areas/layers surveyed were located in serene locations with low human populations where predominant activities include; fishing, wood collection and sand dredging, the release of toxic substances that can be deleterious to sediment quality because of the presence of high concentrations of toxic substances were observed to be low. This also accounted for the low metal concentrations observed.

\section{Acknowledgements}

I would like to appreciate my parents, Mr and Mrs E.O. Diayi for all round support in life, my supervisor Dr A.M. Gbadebo for the time, efforts and patience invested in this project and my lovely wife, Vivian Ndidi Diayi for all the extra mile encouragements.

\section{References}

[1]. APHA. 1992. Standard Methods for the Examination of Water and Wastewater. American Public Health Asociation. Washington DC, USA.

[2]. Department of Water Affairs and Forestry (DWAF). 1996. South African Water Quality Guidelines Volume 7 Aquatic Ecosystem Use. 2nd ed. DWAF, Pretoria, Republic of South Africa.

[3]. Elijah I. Ohimain, Gbolagade Jonathan and Steve O. Abah (2008) Variations in Heavy Metal Concentrations Following the Dredging of an Oil Well Access Canal in the Niger Delta, Advances in Biological Research 2 (5-6): 97-103, 2008, ISSN 1992-0067, (C) IDOSI Publications, 2008.

[4]. Fan W, Wang W-X, Chen J, Li X, Yen Y-F. Cu, Ni and Pb speciation in surface sediments from a contaminated bay of northern China. Mar Pollut Bull 2002;44:816- 32

[5]. Jaji M.O., Bamgbose, O., Odukoya, O., Arowolo, T.A. 2007. Water quality assessment of Ogun River, South West Nigeria. Environmental Monitoring and Assessment. 133:473-482.

[6]. Kuroshima, R. 1992. Cadmium accumulation in the mummichog, Fundulus heteroclitus, adapted to various salinities. Bulletin of Environmental Contamination and Toxicology. 49: 680-685.

[7]. Mgbemena M.N., Obi-Uchendu E.C. and Onwukeme, V.I. (2011) HEAVY METAL POLLUTION OF WATER SEDIMENTS AND PLANTS IN ABA RIVER ABIA STATE, NIGERIA, Journal of Basic Physical Research ISSN: 2141-8403 PRINTS, 21418411 ONLINE Vol. 2, No. 1, pp 18-24, June, 2011 
[8]. Muller, G. 1979. Schwermetalle in den sediment des Rheins-Veranderungem Seit 1971. Umschau. 79: 778-783.

[9]. Ogun-Oshun River Basin Development Authority. 1982. Ogun river Basin feasibility Study, Volume Seven, Tahal Consultantants (Nigeria) Ltd.

[10]. Shelton, L.R and Capel, P.D. 1994. Guidelines for collecting and processing samples of stream bed sediment for analysis of trace elements and organic contaminants for the national water-quality assessment program U.S. Geological Survey Open-file report 94458 Sacramento, California.

[11]. Thomas, D.G., Solbe, J.F., Kay, J. and Cryer, A. 1983. Environmental cadmium is not sequestered by metallothionein in rainbow trout. Biochem Biophys Res Commun. 110 (2):584-592.

[12]. Uaboi-Egbenni P.O., Okolie P.N., Martins O., Teniola O. 2010. Studies on the occurrence and distribution of heavy metals in sediments in Lagos Lagoon and their effects on benthic microbial population, African Journal of Environmental Science and Technology. 4 (6): 343-351. ISSN 1991-637X, Academic Jounal.

[13]. United States Environmental Protection Agency (USEPA). 2004. Water quality monitoring for coffee creek (Porter County, Indiana). http://www.USEPA/Research.htm.mode=62-28-00-00[2006, Sep 29]

[14]. Weltens, R., Goossens, S., and Puymbroeck, S.V. 2000. Ecotoxicology of contaminated suspended solids for filter feeders (Daphnia Magna). Archives of Environmental Contamination and Toxicology. 39 (3): 315-323. 